\title{
Note about Locutions Nominative in Albanian Language
}

\author{
Prof. as. dr. Haredin Xhaferi \\ Faculty of Peshkopi \\ University "Alexander Moisiu", Durres, Albania
}

\begin{abstract}
The object of this article is to describe the locutions worth the name. These locutions not treated in separate studies. It is characteristic that many of them have no words synonymous. They have the phrase structure and express a single concept. This group consists of stable terminology compound words and compound words non terminology. Nomination terminology compound words are formed on a single holistic concept. Unit lexicon - semantic constituent elements is their common feature. Nomination stable compound words are formed from two or more words. Compound words consisting of two elements have the facility two names or a name and a surname. These compound words are not simple names. The designations made by similarity tend to switch to a single word. Their form right is named second in the form of outstanding free. The process of transition to a question set according to their names, composition, content, consent, damage, connotation is the later. Regular forms of these compound words is the name of the second non ablative outstanding. Compound words formed by a name and a surname are used to sense directly or figurative sense. Compound words formed by more than two words have the structure only comes with complete understanding or words with full understanding and sense incomplete. They are few, but are diversified by their structure and value. Locutions name value are many and various.
\end{abstract}

Keywords: idiom, phrase stable, terminological phrase, phrase not terminologies, structure, limb, semantic value, meaningful words, words not meaningful

\section{Introduction}

Identify and reflect locutions the value of a variable part is difficult. This relates to the presence of phraseological units with value of these categories lexicon - grammar. The difference between them is not always easy, because many features these units have in common. In linguistic literature during treatment variable parts of speech are not mentioned at all locutions the value of words contained in each of these parts. For the first time they are mentioned by Sheperi I. D. (Gramatika dhe sindaksa e gjuhës shqipe). M. Domi recognized as such locutions mainly structures origin of verbal lokucionet as: të bërët ballë (bëj ballë), të vënët re (vë re), të ngriturit krye (ngre krye) etc. , and the designations of free simple, as: Iule akulli (Iulja e akullit), lule blete, lule dimri, lule dhensh, bar ethesh, bar dielli, gjel deti etc. (Disa çështje të lokucioneve)

Nominal characteristic locutions is that many of them have no words synonymous. These locutions have the phrase structure. Through notions that express limbs, they reflect the reality of relationships between objects or objects and their attributes. These links are stable, not created at the time of the lecture.

Locutions are not worth category name lexicon - grammar. Such constructions are usually presented with two limbs. Constituent elements are about dependency, being distinguished define country and determinant, (A. V. Desnickaja, Mbi strukturën morfologjike të gjuhës shqipe) fused to a single notion. A. Kostallari made this observation about the word made up. (Mbi disa veçori të fjalës së përbërë në gjuhën shqipe) These units are piles consistent with the definition of racial or attributive. Having lost one basic understanding of the elements and, gaining new understanding of the whole structure, idioms approaching unit. (Parimet themelore për hartimin e "Fjalorit të gjuhës së sotme shqipe")

Their constituent elements do not have that degree of stability that have elements of phraseological compound words. The links between these elements are straightforward, such as real connections between objects or objects and their properties. Generally these units are formed according to certain models. Their creation is a continuous process and it is now a trend of our language. This trend has extended into the field of terminology and off the field, in general language.

Locutions the value of a name composed of terminology sustainable compound words and non terminology. To date these linguistic units in general lexicon no special studies. The most studied are stable compound words terminology. They 
are formed on a single concept thorough and semantically express a single concept. J. Thomai, a part of these compound words has been included in a separate group names phraseological units (Frazeologjizma emërorë dhe mbiemërorë në gjuhën shqipe). Later excluded from the wording. They are formed by some of these compound words and some other constructions phrase structure. (Fjalor frazeologjik i gjuhës shqipe). This scholar has called platoons consisting designations: bombë dore, këpucë me qafa, pullë poste, punë dore, detyrë shtëpie, rend dite, bibliotekë kombëtare etc. and has excluded from the phraseology, while platoons: gjuhë lope, gjurmë mushke, bisht lepuri, gojë asllani, gjuhë nuseje, këmbë pate, hith të vdekuri, nusja e lalës, kali i qyqes, lakuriqi i natës, Kashta e Kumtrit, Arusha e Madhe, molla e Adamit etc. has called simple terms without, and included in phraseology (Çështje të frazeologjisë së gjuhës shqipe). According to him, such terms have pure nominative function, while expressiveness is absent or too weak (A. Duro has noted that the stable compound words terminology idiom is weaker, because they have no stylistic or emotional burden. (Terminologjia si sistem), although trope (J. Thomai, Fjalor frazeologjik i gjuhës shqipe).

A. Duro construction këpucë me qafa, bombë dore dhe bibliotekë kombëtare has included the three types of stable compound words not phraseological nominal value: general (këpucë me qafa); terminology (bombë dore) and the character of nomenclature (bibliotekë kombëtare). Stable compound words terminology has called a special category of albanian vocabulary (A. Duro, Terminologjia si sistem). He has handled sustainable nominal compound words that are used as terms, helping to create a clearer concept on them, to distinguish from free compound words, the free compound words terminology and sustainable compound words phraseological. The author has distinguished unit lexicon - semantics of the constituent elements as the common feature of all compound words consistent with the value of a name. They feature denominator, mark an object or phenomenon of reality. (Togfjalëshat e qëndrueshëm terminologjikë në shqipen e sotme)

M. Samara recognized as stable compound words platoons nominal marrja parasysh, pasja kujdes, heqja dorë, marrja e masave, dhënia llogari etc.

M. Samara recognized as stable compound words platoons nominal marrja parasysh, pasja kujdes, heqja dorë, marrja e masave, dhënia llogari etc. (Antonimia e togfjalëshave të qëndrueshëm në gjuhën e sotme shqipe). A. Spahiu accepted as nominal locutions structures such as: Arusha e Madhe, Arusha e vogël, molla e Adamit, nusja e lalës, Qafa e Thanës, i zoti $i$ shtëpisë, zënia besë, vënia re etc. (A përbëjnë lokucionet një mënyrë të veçantë fjalëformimi). J. Thomai these units included the wording of names. (Fjalor frazeologjik i gjuhës shqipe).

\section{The structure of compound words consistent with name value}

Nomination stable compound words are diversified by semantic and structural composition. The following analysis will be done with the subject mainly from areas of flora and fauna, but also from any other field of general vocabulary. These compound words will be monitored by the structure and their form of use. They are formed by two or more words.

\section{Stable compound words formed from the names of two words}

There are numerous. They are formed by two names or a name and a surname.

1. Nomination stable compound words formed by two names. Comprise large numbers. They are diversified by morphological forms of names of account.

1. 1. Nomination stable compound words formed by two names in the form of outstanding free are numerous. These include quite simple names without flora, fauna, geography, astronomy etc. These designations are made on the basis of similarity, affiliation or other semantic connections. They are formed by name in crumples names + noun in the nominative case or ablative.

1. 1. 1. Designations formed by two names in in nominative have second name figurative sense. Links between the two limbs are determinants. ( $F$. Leka called this type of compound words quite manufacturer in the field of terminology, bringing examples tryelë elikë, sharrë disk, limë piatë, vinç kullë. (Aspekte të zhvillimit të terminologjisë tekniko - shkencore pas Çlirimit). These designations are made on the basis of similarity. the similarity comes from the comparison of one thing he a part of it (the first limb of comparison) with another object or a part of it (the second limb of the comparison). The limbs of comparison can be expressed both or just one of them. 
a. Designations that have the structure of the two limbs of comparison, are formed on the basis of direct comparison. The first name is the direct use. Morphological its shape is case nominative singular. The second name is the use of the trope. Morphological its shape is the ablative. (Disa çështje të lokucioneve) or without this termination. Feature in these structures forwarded only to a degree. Thus, to name bar iriqi which means "Herbaceous plants by cuttings short year with numerous ramifications, which end at their peaks with small leaves of money as needles, giving the whole plant body shape the hedgehog," feature followed by direct comparison with the hedgehog plant. Such mention: Iule fasule "Plants like beans ... "; Iule gjarpër "Herbaceous perennial plants, trailing ... " etc. Are in smaller number compared with other groups.

Form the termination is not justified for all aliases of this group. Form the termination is not justified for all aliases of this group. They should be used without ending the second name: bar iriq. Form without termination allows for the passage in question comprised: baririq. (F. Leka, Aspekte të zhvillimit të terminologjisë tekniko - shkencore pas Çlirimit). Passing in question facilitates their use in different contexts. Thus, we can say: gjethet e baririqit, but not të barit të iriqit, because we leave the naming semantics. For this category label is irregular use of the name of the second gender. In this structure form the phrase first used the name in outstanding form and the second named outstanding free: bari iriq.

b. A label type structure have in the name of the item (plant) and the name of a foreign entity with which a comparison is made. Although the name of the plant is used, the comparison is done with her part, whose name is not naming structure. Comparison of these structures is not straightforward. Feature followed in two steps: at first passes the part and then to the whole. For example. , to name lule shqiponje, which means "Perennial, always green, with large leaves and deep cut, similar to the wings of an eagle ..., , followed part feature (leaf) by matching eagle and then passes to the entire (plant) through sinecdoce. Even in these designations second name should be used without ending the ablative: Iule shqiponjë. It is right that the unit be used as a compound word: Iuleshqiponjë or first name in outstanding form: Iulja shqiponjë. Using second-gender name is abnormal even in denominations of this group. Of this type are: bar fier "Year herbaceous plant, with leaves similar to fier ... "; bar gjarpër "Herbaceous perennial plant, with leaves gray-green, dark on the top, with bright brown scales on the bottom ... " etc. (K. Cipo in an article about naming composite lule lakër, treated by decomposing in "a flower that sprouts" or "a cabbage that is flowers. "According to him, the second limb apposition taken as a first attribute of the limb. (Rreth disa kompozitave) It is rich group.

Naming of this subgroup in the vocabulary of today's Albanian language are reflected in two forms: as compound words and how words: Iule krehri and lulekrehër, lule lakre and lulelakër, luleshpatë and lule shpate, lulerruazë and lule rruaze etc. (Fjalor i gjuhës së sotme shqipe) These names can be used as a single word, because qualify language, as well as names of the first group (a).

1. 1. 2. Designations formed by a name in crumples name and a name in the ablative have names relating directly. These designations are made on the basis of similarity or affiliation, composition, content, consent, damage, connotation etc.

a. A separate type of account names that have the structure of the second limb of comparison, represented by the name of part of a foreign entity and the name of the owner of that part. Are a subset of the rich. Such are: bisht daci "Herbaceous plants year, dump shaped leaves, with white bloom on the tree, on top of the stem, the shape of the tail of the cat ... "; bisht gomari "Herbaceous plants to a meter high, with money leaves long as needles ... " etc. The limbs of these compound words are in close affiliation. At first these structures have been enhanced with the name of the plant as the first element: bar (lule) bisht daci etc. (J. Thomai states that the names of this type colloquially used as adjectives (Frazeologjizma emërorë dhe mbiemërorë në gjuhën shqipe). Later today the structure is narrow and has the form of a simple phrase.

The first name of these compound words trope is in use. He fashioned notion that transmitted the first limb of the comparison, which is not expressed. To better understand this, we label illustration bisht dhelpre, which has A. Kostallari treated as composite. (Mbi disa veçori të strukturës semantike të kompozitave pronësore të shqipes). He explained that this label is not broken down into "plant that has tail like a fox," but "leaf plants such as foxtail. " (Mbi disa veçori të strukturës semantike të kompozitave pronësore të shqipes). In the definition given there are three keywords (three component strands): plant - leaf (leaf) - foxtail. The first word is the name of the plant (the subject or the owner); The second word is the name of the part (of property), and phrase marks characteristic of the part. Linking the subject property is straightforward, while determining bond components (phrase) with the name of the part is figuratively (by comparison). The phrase bisht dhelpre, when the direct use, has elements about free. When used as a label, related elements are stable in high degree. (A. Duro, Terminologjia si sistem). Morphological form is regular. Even in this group feature names followed 
by two stages (see also the group b). The notion that belongs to an organic part of a foreign entity, the forwarded part of the subject in question (by comparison) and the latter forwarded to the subject itself.

In spelling are not taken into account the above criteria semantics for writing these units. (Drejtshkrimi i gjuhës shqipe). Naming of this type are written as a single word in the dictionary spelling. (Fjalori drejtshkrimor i gjuhës shqipe) In other dictionaries are written in two forms either as a single word. (Fjalor i gjuhës së sotme shqipe; Fjalor i shqipes së sotme) The second name of these structures emerges in ablative outside naming connections, whenever she, on the basis of a new understanding gained, names another object. This morphological form retains its name even when the structure is used as a cheap phrase.

b. A group designations of this type are placed according to their structural, content, attendance, damage, use etc. The second name of these designations is singular or plural number of outstanding free. Such can make: bar beronje "Herbaceous perennial plants in the clutch, similar to oregano leaves, white flowers that grow normally in the rocks and used in folk medicine for women who are not born"; bar bibe "Herbaceous plants with long leaves of money arising herd near the root, with downy white flowers, used for the treatment of jaundice of duckling"; lule shkëmbi "Herbaceous plants with red flowers, leaves thin and long, that grows in the rocks"; lule vjeshte "Herbaceous plant with white flowers in purple, blooms in the fall ... " etc.

The second limb of these designations used on gender, when in the form of outstanding (Gramatika e gjuhës shqipe I) as in Albanian, as a rule, the ablative replaces semantically prominent gender crumples (L. Buxheli, Modelet e caktimit rasor në gjuhën e sotme shqipe). Thus, the unit lule shkëmbi can be used and lule (lulja) e shkëmbit, lule vere and lule (lulja) e verës, bar pleshtash and bar (bari) i pleshtave, lule dhensh and lule (lulja) e dhenve, gur zjarri and gur (guri) i zjarrit etc. (Xh. Gosturani, Rasë rrjedhore apo gjinore?)

The designations of the group and subgroup 1.1.1. $\mathrm{c}$ not end in question, because the relations established between the limbs of the second limb necessarily require the ablative. Albanologist $\mathrm{G}$. Weigand has called composite word compound words name name outstanding free in ablative, as bri dreri, ve rosash, këlysh macesh etc. , whose evident connections between the concepts that express limbs. (Albanisiche Grammatik in sudgegischen Dialekt, Leipzig, 1913). This attitude has supported Cipo K. , who has called composite sui generis. He has brought as examples: : gur kufiri, bukë gruri, ve pate, lëng pule, lule dhensh, voj ullish, zoq pulash, bukë fiku, gojë asllani, some of which included the locutions the value of a name (Gramatika shqipe; Sintaksa).

Maintaining the treatises of free gadgets outstanding (flektiv element) turns them into units with incomplete grammatical structure and incomplete paradigm bending. (L. Buxheli, Raste në kapërcyell midis emrave të përngjitur dhe togfjalëshave të qëndrueshëm) A. Kostallari type designations over the country residence, domicile etc. In a word explained by the decrease of the endings. This decline, according to him. Shapes neutralizing grammatical relations that exist between the components in the appropriate phrase. When used as a compound word, the second element defines the first element in a more general (Mbi disa veçori të fjalës së përbërë në gjuhën shqipe). In our opinion, the right is the second name of the structures used in gender, although these forms are homonymous with free forms of compound words. The difference between them during use makes context.

For these designations transition process in question seems overdue. It will be done when endings of the ablative become sound theme or termination of the outstanding treatises.

Although these structures have limbs see a general name that names a certain class tableware and second limbs of a name that indicates the feature classification, quality, location, time, composition, ethnicity etc. , the whole structure has acquired new meaning and names a single object. (F. Agalliu, Rreth përdorimeve të rrjedhores në shqipen e sotme letrare). It has taken the form of a stable non-phraseological phrase. These designations are included in the group of stable compound words terminology. This justifies their reflections in the explanatory dictionaries, marking and relevant field. Even determining their shape is regular script. (Drejtshkrimi i gjuhës shqipe). Such structures are compound words name value and should not be written as a single word. In dictionaries noticed misspelled forms, such as luleborë, luledele etc. (Fjalor drejtshkrimor i gjuhës shqipe) or in two forms, such as lule dielli and luledielli, panxhar $i$ sheqerit and panxharsheqeri etc. (Fjalor i gjuhës së sotme shqipe). 
A. Kostallari brings several examples of coverage of this type of compound words in dictionaries monolingual or bilingual early Eagles. Structures such as vaj gur, mizë kali, gur kali, gur zjarri, qymyr guri etc. are reflected in various forms in different dictionaries or in a dictionary. This fluctuation in the writing of these units he saw as "an unfinished process of transition from a word attached to a word composed of racial designation. " (See Mbi disa veçori të fjalës së përbërë në gjuhën shqipe. ) Recognizing the genetic link between words and words composite absolute, he thinks quite structures, such as vendbanim, vendlindje, datëlindje, pikënisje, bregdet, vendqëndrim, vendstrehim etc. , who eventually passed in question composite, have origins in attachment of piles of words that compose them. Origins of words composed of absolute words have also accepted foreign scholars. K. Brugman words composite base has found the combinations (platoons) syntactic (Über das Wesen der sog, Wertzusammmensetzung), while A. Maillet - J. Vendryes have called possible origin of composition by juxtaposition (Traité de Grammaire des langues comparée classiques).

At first these units are built as compound words branding free. Thus, the structure of the bar shkëmbi "Herbaceous plants year, like clover leaves, with small seeds, collected in bean sprouts, grows in rocky high places" was built by the general name bar, which names all kinds of drugs and name shkëmb, used by the country where the plants germinate. This facility can be used for any type of grass that grows in the rock. How sustainable phrase she used only for a particular type of plant that grows in the rock, although there also grow many other types of herbs, which are labeled with the names according to the knowledge and the characteristics of their special features.

These units come not from the semantics of compound words that constitute limbs, but the grammatical form of the name of the second. Large numbers represent units formed from a more general name or a name that is used for a certain class of things, according to the most general characteristics, such as bar, lule, gjemb etc. and a name of animal, bird, etc. , related in various ways to the plant. For example. bar qumështi "Herbaceous plants of one year, with leaves shaped dump ... graze more cattle"; bar moçali "Herbaceous plants year ... . which grows in swampy places, causes disease in cattle pit"; bar rripe "Herbaceous perennial plants, . . . that grows in rocky places"; bar plehu "Herbaceous plants year . . that grow in ruins"; lule vjeshte "Herbaceous plant with white flowers in purple, blooms in the fall . . ."; lule vere "Herbaceous plant with oval leaves, almost round, yellow flowers that bloom in summer"; Iule balsami "Herbaceous plants, used in folk medicine to treat wounds" etc.

1. 2. Nomination stable compound words formed by without prominent name + name outstanding is the name of meaning or general impersonal. Names in these structures may use direct or trope. The first name appears in the names of outstanding free, while the second comes in the name of gender. The latter can be used in ablative the outstanding free connections just outside the locution. These structures are stable compound words terminology. Included are: mollë $e$ Adamit, Kashtë e Kumtrit, Udhë e Qumështit, YIl i Karvanit, Qafë e Thanës, Qafë e Shtambës, Qafë e Buallit, Majë e Hekurave, Ditë e Verës, pikë e ngopjes, e bardhë e syrit (syve) etc.

2. Nomination stable compound words formed by a name and a surname. Are less than the compound words formed by two names. Surname characterizes the object directly or figuratively.

2. 1. Nomination stable compound words formed by name + surname direct sense are names that have the structure an adjective quality. Surname characterizes object or a part of it.

2. 1. 1. Designations formed by a name and a surname that characterizes the object as a whole, constitute a significant number. Adjectives show a common characteristic feature of the item. For example. , gjemb i shkurtër name meaning "Thorn . . . , to increase slightly. " fasule e shkurtër "Beans . . . which grows less"; labot i butë "Herbaceous plants year . . . that is cultivated in gardens as plants for food"; murriz i bardhë "Shrubs with multiple branches with sharp thorns, leaf sprung, with white flowers ... "; dhi e egër "Animal chewable mammals, similar to goat . . . who live in the high mountains of the rugged" etc. From other areas bring: trysni e lartë, ingranazh i madh, aeroplan gjuajtës, vijat e verdha, vijat e bardha etc. For example. Një rrapëllimë e fuqishme çau ajrin; në fushë lëvizën dy aeroplanë gjuajtës. - Nuk të lënë të ndërtosh këtu, se paska dalë një vendim për vijat e verdha, - tha Batoja.

2. 1. 2. Designations formed by a name and a surname that characterizes a part of the property are numerous. Name of part may or may not be an element of naming structure.

a. The designations bar luleverdhë "Herbaceous plant with slender stalk branched, with a yellow flower on top of each estuary ... "; cërre krahkuqe " Bird with small body, the color of dark body feathers and down red wings" etc. have the name of the first limb portion of the second element (surname). 
b. Designations tërfil i ashpër " Plants like clover. .. , with large leaves, strong and tough on the surface"; bar i hollë "Herbaceous plants without stalk, with long leaves of money as needles, that grows in meadows" etc. do not have the name of the part structure. Feature forwarded to the subject through synecdoce. So, denomination bar $i$ zi means "The one year herbaceous plant small grains, sewage ... " Black surname characterizes a part of the plant (fruit) and through part feature forwarded plant. Thus naming names seen from the two limbs names.

2. 2. Stable compound words nominative form of the name + surname meaning trope have the structure adjectives that characterize an object by similarity. Thus, shelg lotues name means "Kind willow branches epshme's very long, which hang down. " Such are: fasule qorre "Beans with very small grains"; dredhje zvarranike "Kind dredhjeje to stalk lying"; Lumi i Vdekur, e premte e zezë etj. For example. Lumi i Vdekur, me atë ujët e tij të ndenjur e të mbuluar me lëmashk, ngriu gjer afër grykës, se më tej s'e lanë valët e Adriatikut, ndërsa këneta e cekët e bëri këtë punë më shpejt. E premtja e zezë është dita kur është varrosur Krishti.

2. 3. Stable compound words nominative form of the name with the figurative sense + surname direct sense are few. Appointments are impersonal sense, as Qerrja e Madhe, Qerrja e Vogël, Arusha e Madhe, Arusha e Vogël etj. For example. Përtej perdeve prej dantelle ne shihnim të hutuara qiellin që Arusha e madhe dhe yjet e tjera e shponin të shndritshëm e të paarritshëm dhe na bëhej se ato na dërgonin një mesazh të pazbërthyeshëm, të largët qindra vjet dritë.

\section{Stable compound words formed from the names of more than two words}

Are less in comparison with compound words of the first group (I). Their structure is varied by category lexicon - grammar of words that make up and the order of those words.

1. Stable compound words nominative form by scoring words. Are different from the lexicon category - grammatical constituent words and their morphological shapes. These words may be names or surnames.

1. 1. Nomination stable compound words formed by the names are rich group. They have the features of compound words with two words 1. 1. 1. c. group. Structural difference between them is distinguished by the presence of more than two names. This group includes several subgroups:

a. Designations established by name in the nominative + a free phrase (noun + noun) constitute rich group. In these structures is expressed first limb of comparison. The phrase that carries the determinant function, used in the form of stony silence. The structure bisht dhelpre second name when using gender crumples put both names changed (bishti i dhelprës, bishtin e dhelprës etc. ), as the phrase bombë dore. The phrase karafil gjethe pishe simple phrase gjethe pishe used petrous, changing only the name of cloves. Such are the compound words: cefalare pelin deti, ciklamin gjethe urthi, dardhë gjethe hunapi, dardhë kofshë pule, hudhër erë myshku, karafil ngjyrë gjaku, klokëz brinjë kau, kokoçel bar zgjebeje, kokoçel gjethe rrëshyelli, kuqël dhëmb qeni, lëpjetë kokë kau, lëpjetë lule vishkulli, lulekambanë gjethe pjeshke, milëz bisht akrepi etc.

b. Designations formed by a terminological phrase (noun + noun) + a prominent name in gender are the smallest group. In the present structure is not the first limb of the comparison. Name out simple phrase structure stable performs the function of determinant and differentiates the type. Such are: bisht dhelpre e arave, bisht kali i ujit, bisht miu i Greqisë, gjuhë lope e arës, gjuhë lope e Kretës, gjuhë qeni i kolonës, lule balsami e malit etc. When using these compound words change to three names. Thus, it is said: Këputa bishtin e dheplrës së arave.

c. Designations formed by a terminological phrase (noun + noun) + a free phrase are in limited numbers. Such are: bisht miu gjethe lisre, gjilpërë qyqeje sqep shtërgu, gjilpërë qyqeje sqep çafke, gjilpërë qyqeje erë myshku etc. These compound words are distinguished not only by the number of components, but also morphological forms of these elements. They are formed by a phrase consistent with the use of figurative and a free phrase, first limb of which served for comparison. Although it is free phrase out of this denomination, in its structure he used petrous: bisht miu gjethe listre, bishti i miut gjethe listre, bishtin e miut gjethe listre etc.

1. 2. Stable compound words nominative form of names and surnames are numerous. These designations are formed by two names and a surname or a name and two surnames.

a. Designations formed by a phrase (noun + noun) and an adjective have the name of the second phrase in non ablative outstanding. Outside the phrase naming structure functions as set by similarity label or affiliation. Surname characterizes object named by the phrase, specifying the type. Such are: bisht miu lulevogël, bisht qeni gjembak, brinjë kau gjethegjatë, 
bar presi fletëgjerë, bisht akrepi grremçak, grurë zhulicë e bardhë, gjilpërë qyqeje butëloshe, gjuhë lope e kaltër, gjuhë nuseje e çarë, gjuhë qeni gjerman, kashtë kënete e gjatë, këmbë maçoku bregdetar, këmbë sorre e kuqe, lule balsami mjekëroshe, lule dimri ombrellore, lule maji e kaltër, menekshe gomari ballkanike, dac deti i vogël, dallandyshe deti e zezë, qen deti gjembak, zog bari sqepshkurtër etc.

b. Designations formed by a phrase (name + surname) and an adjective, although the two adjectives structure, have the characteristics of a group designations. Name and surname of the first off naming functions as terminological phrase. Second surname express what names feature the phrase, being connected steadily with. The three elements form a stable extended phrase. There constitute large number: cërlua i zi pikalosh, gjelëz e madhe bishtzezë, hundëgjatë $i$ vogël dhëmbëbardhë, hundëgjatë xhuxh dhëmbëbardhë, lakuriq i madh hundëpatkua, rosë e egër e zezë, rosë e përhime rozë, qukapik larosh kurrizbardhë, zhytës i vogël laraman, kokërrujë e purpurt e kaltër etc.

c. Designations formed by a phrase (name + surname) and a prominent name in the gender make up the small group. In the relevant terminology used phrase gender designation, while the gender determines the type name. Such are: peshk kavall i detit, peshk kavall i lumit, kërpudhë pufkë magjari etc.

2. Stable compound words nominative form by scoring word and word service. There are numerous. Words scoring may be two names that belong to the same semantic field or fields. The word service is preposition.

2. 1. Stable compound words formed by prominent name without + preposition + noun outstanding free account group had. Prepositions used in these designations are with or without the racial accusative.

a. Naming the preposition me are large group. In these structures names may use direct or trope.

- Designations nenë me farë, bar me kalli, bar me kokë, rrush me erë, rrush me ujë, zog me lafshë, pështrik me vile, mizë me thumb, gjarpër me çapar, skort me vizë, manometër me zhivë, trapano me vidhë etc. have direct user names. The meaning of the name designation carries with preposition, however, the whole phrase expresses a single concept.

- Designations pështrik me baluke, bilbilth me mustaqe, gjarpër me syze, gjarpër me zile, pulë me mjekër, zogth me veshë etc. the second name have to use the trope. Even in these designations name conveys the sense of naming preposition.

b. Naming the preposition without are fewer. Such as: bulonë pa kokë, hutë pa veshë etc. The presence of preposition pa without showing lack of something to a thing by comparing it with other items of that type.

2. 2. Nomination stable compound words formed from a phrase terminological + preposition + noun are few, like: lule balsami me njolla, rosë laramane me çafkë etc. Name the accusative differentiates the type of sex. Links are direct elements. All the phrase expresses a single concept, a plant names.

3. Sustainable nominal compound words formed from a phrase terminological $+s i+$ noun in the nominative are quite rare. These designations are made on the basis of comparing twofold: first, gender denomination was formed based on the comparison of the synecdoce, then the name of the type is formed on the basis of comparison. A second comparison is evident from the presence of both his limbs and vibrating presence of comparison. Included are: bisht luani si zemër, bisht akrepi si krimb etc.

\section{Conclusion}

Locutions value are many and various. During this analysis we tried to reflect some of the structural types of compound words terminology. The diversity of their semantic and structural elements degree of sustainability etc. Requires more extensive study and detailed. In this study, as noted above, are mainly reflected the structures of simple labels without flora and fauna, bringing in some cases examples from other areas.

\section{References}

Agalliu, F. , Rreth përdorimeve të rrjedhores në shqipen e sotme letrare, SF, 1, 1990 
Brugman K. , Über das Wesen der sog, Wertzusammmensetzung, Leipzig, 1900

Buxheli, L. , Çështje të shkrimit të fjalëve të përngjitura dhe të disa strukturave analitike, Shqipja në etapën e sotme: politikat e përmirësimit dhe të pasurimit të standardit, 2011

Buxheli, L. , Modelet e caktimit rasor në gjuhën e sotme shqipe, 2007

Buxheli, L. , Raste në kapërcyell midis emrave të përngjitur dhe togfjalëshave të qëndrueshëm, Gjuha jonë, 1 - 4, 1994

Cipo, K. , Gramatika shqipe, 1949

Cipo, K. , Rreth disa kompozitave, Studime mbi leksikun dhe mbi formimin e fjalëve në gjuhën shqipe, I, 1972

Cipo, K. , Sintaksa, 1952

Desnickaja, A. V. , Mbi strukturën morfologjike të gjuhës shqipe, Buletin i Universitetit Shtetëror të Tiranës, Seria e shkencave shoqërore, 3, 1959

Domi, M. , Disa çështje të lokucioneve, Studime filologjike, 1, 1985

Drejtshkrimi i gjuhës shqipe, 1973

Duro, A. , Terminologjia si sistem, 2001

Duro, A. , Togfjalëshat e qëndrueshëm terminologjikë në shqipen e sotme, Studime filologjike, 4, 1982

Fjalor i gjuhës së sotme shqipe, 1980

Fjalor i shqipes së sotme, 1984

Fjalori drejtshkrimor i gjuhës shqipe, 1976

Gosturani, Xh. , Rasë rrjedhore apo gjinore? Studime filologjike, 3, 1989

Gramatika e gjuhës shqipe, I, 1995

Kostallari, A. , Mbi disa veçori të fjalës së përbërë në gjuhën shqipe, Studime mbi leksikun dhe mbi formin e fjalëve në gjuhën shqipe, I, 1972

Kostallari, A. , Parimet themelore për hartimin e "Fjalorit të gjuhës së sotme shqipe," Studime mbi leksikun dhe mbi formimin e fjalëve në gjuhën shqipe, II, 1972

Leka, F. , Aspekte të zhvillimit të terminologjisë tekniko - shkencore pas Çlirimit, Studime filologjike, 1, 1970

Maillet, A. - Vendryes, J. , Traité de Grammaire des Langues comparée classiques, 2e ed. Paris, 1948

Samara, M. , Antonimia e togfjalëshave të qëndrueshëm në gjuhën e sotme shqipe, Studime filologjike, 4, 1981

Sheperi, I. D. , Gramatika dhe sindaksa e gjuhës shqipe, 1927

Spahiu, A. , A përbëjnë lokucionet një mënyrë të veçantë fjalëformimi? Gjuha jonë, 1 - 4, 2005

Thomai, J. , Çështje të frazeologjisë së gjuhës shqipe, 1981

Thomai, J. , Fjalor frazeologjik i gjuhës shqipe, 1999

Thomai, J. , Frazeologjizma emërorë dhe mbiemërorë në gjuhën shqipe, Studime filologjike, 4, 1975

Weigand, G. , Albanisiche Grammatik in sudgegischen Dialekt, Leipzig, 1913 